What Is Medicine? 
The publisher gratefully acknowledges the generous support of the Sue Tsao Endowment Fund in Chinese Studies of the University of California Press Foundation. 


\section{What Is Medicine?}

W ESTER N A N D EA STER N

A P P R O A H E S T O H E A L I N G

P A U L U . U N S C H U L D

Translated from the German by Karen Reimers

甲

UNIVERSITY OF CALIFORNIA PRESS

Berkeley Los Angeles London 
University of California Press, one of the most distinguished university presses in the United States, enriches lives around the world by advancing scholarship in the humanities, social sciences, and natural sciences. Its activities are supported by the UC Press Foundation and by philanthropic contributions from individuals and institutions. For more information, visit www.ucpress.edu.

University of California Press

Berkeley and Los Angeles, California

University of California Press, Ltd.

London, England

(C) 2009 by The Regents of the University of California

Library of Congress Cataloging-in-Publication Data

Unschuld, Paul U. (Paul Ulrich).

[Was ist Medizin? English]

What is medicine? : Western and Eastern approaches to healing /

Paul U. Unschuld ; translated from the German by Karen Reimers.

p. $\mathrm{cm}$.

Includes index.

ISBN 978-0-520-25765-8 (cloth : alk. paper)

ISBN 978-0-520-25766-5 (pbk. : alk. paper)

1. Medicine-Philosophy-History. 2. Medicine, Oriental-

Philosophy-History. I. Title.

[DNLM: 1. Philosophy, Medical. 2. Cross-Cultural Comparison.

3. Medicine, East Asian Traditional. w 61 U59 2009]

R723.U56 2009

$610.1-\mathrm{dc} 22$

Manufactured in the United States of America

$\begin{array}{llllllllll}18 & 17 & 16 & 15 & 14 & 13 & 12 & 11 & 10 & 09\end{array}$

$\begin{array}{llllllllll}10 & 9 & 8 & 7 & 6 & 5 & 4 & 3 & 2 & 1\end{array}$

This book is printed on Cascades Enviro 100, a 100\% post consumer waste, recycled, de-inked fiber. FSC recycled certified and processed chlorine free. It is acid free, Ecologo certified, and manufactured by BioGas energy. 
To Charles Leslie,

friend and mentor. 
This page intentionally left blank 
Plausibility is the brother of truth. 
This page intentionally left blank 